\title{
Analysis of predictive and prognostic factors in 290 patients treated with oncolytic adenoviruses
}

\author{
Kristian Taipale ${ }^{1 *}$, Ilkka Liikanen ${ }^{1}$, Anniina Koski ${ }^{1}$, Anna Kanerva', Minna Oksanen ${ }^{1}$, Akseli Hemminki \\ From 30th Annual Meeting and Associated Programs of the Society for Immunotherapy of Cancer (SITC 2015) \\ National Harbor, MD, USA. 4-8 November 2015
}

\section{Background}

After years of development, oncolytic viruses are nearing a breakthrough into clinical use. In order to facilitate the implementation of this new form of immunotherapy, all existing clinical experience must be utilized to optimize treatment strategies, improve patient selection and develop even more effective oncolytic therapeutics.

Here we report clinical factors that affected the prognosis and predicted treatment efficacy in 290 patients treated with oncolytic adenoviruses. In these analyses, survival and efficacy determined by radiological response criteria were used as dependent variables in multi-parameter regression models. In prognostic models measuring hazard ratio (HR) for cancer mortality, tumor type and virus arming were found to affect the prognosis of the patients significantly. Gynecological tumors were notably linked to better prognosis (HR 0.477, $\mathrm{p}=0,004)$. Patients treated with viruses coding for GMCSF (HR 0.549, $\mathrm{p}=0.003$ ) or GMCSF-coding viruses and CD40L-coding viruses (HR $0.439, \mathrm{p}=0.023$ ) were more likely to survive longer. In the predictive models the administration of the virus was discovered to independently influence the efficacy of the treatment. Patients who received most of the treatments as intraperitoneal injections were more likely to achieve disease control status (OR 3.878, $\mathrm{p}=0.016$ ). In a small subset of patients $(n=13)$ who received all treatments intravenously the probability of disease control was even higher (OR 8.995, $\mathrm{p}=0.032$ ).

\section{Conclusions}

These data indicate several options for further development of oncolytic adenovirus therapy. Concentration on sensitive diseases and choosing the right patient subsets for treatment, as well as finding optimal administration schemes, are key steps in improving the therapeutic

${ }^{1}$ Cancer Gene Therapy Group / University of Helsinki, Helsinki, Finland Full list of author information is available at the end of the article efficacy of adenoviruses. The results suggest that evaluating the immunological status of the patients before oncolytic virotherapy can offer important prognostic information. In order to be translated to the field of personalized oncology, this concept requires still further investigation.

\section{Authors' details}

${ }^{1}$ Cancer Gene Therapy Group / University of Helsinki, Helsinki, Finland. ${ }^{2}$ Cancer Gene Therapy Group, Medicum, Haartman Institute, University of Helsinki, Helsinki, Finland. ${ }^{3}$ TILT Biotherapeutics Ltd, Helsinki, Finland.

Published: 4 November 2015

\section{doi:10.1186/2051-1426-3-S2-P344}

Cite this article as: Taipale et al:: Analysis of predictive and prognostic factors in 290 patients treated with oncolytic adenoviruses. Journal for Immunotherapy of Cancer 2015 3(Suppl 2):P344.
Submit your next manuscript to BioMed Central and take full advantage of:

- Convenient online submission

- Thorough peer review

- No space constraints or color figure charges

- Immediate publication on acceptance

- Inclusion in PubMed, CAS, Scopus and Google Scholar

- Research which is freely available for redistribution
() Biomed Central 